\title{
Trestný čin velezrady jako hlavní doklad existence „federal common law of crimes“. Americké federální soudnictví v prvých desetiletích nové státnosti
}

\author{
Radim Seltenreich
}

Právnická fakulta Univerzity Karlovy

Kontaktni email: seltenre@prf.cuni.cz

The Crime of High Treason as the Evidence of the Existence of the "Federal Common Law of Crimes". The American Federal Judiciary in the First Decades of the New Statehood

\begin{abstract}
:
In this article the author deals with the problematics of the "federal common law of crimes" in the period since the foundation of the American statehood till the end of the 18th century whereas he claims that the existence of this law is illustrated especially by the negotiation of the crime of high treason on the federal courts. In this connection he deals firstly with the organization of the federal courts on which were these cases negotiated.

Further part covers the concept of the crime of high treason in earlier English law because from this law exactly the American federal courts had to go out. The main part of the article is devoted to the depiction of the concrete judicial pleas related to high treason which were negotiated at that time. Finally, the author mentions some other crimes which may be put in the category of the "federal common law of crimes" as well.
\end{abstract}

Key words: federal common law of crimes; federal courts; high treason

Klíčová slova: "federal common law of crimes”; federální soudy; velezrada

DOI: $10.14712 / 2464689 X .2021 .4$ 
Tento článek si za svůj předmět zvolil historicko-právní poznání velmi zajímavé části rozhodování amerických federálních soudů v prvých desetiletích nové americké státnosti. Je to totiž doba, kdy stále ještě poměrně pochopitelně není ustálen rozsah rozhodovací pravomoci těchto soudů, a kdy se v souvislosti s tímto problémem diskutuje zejména otázka existence tzv. „federal common law of crimes“.

Důležitým vodítkem při diskusi o rozsahu této jurisdikce zde přitom byl zejména oddíl článku 34 zákona o soudnictví z roku 1789, který konstatuje, že „budiž dále rozhodnuto, že právní řády jednotlivých států, nebudou-li v rozporu s ústavou, smlouvami či předpisy Spojených států, mají být považovány za pravidla rozhodování všech soudních procesů, na něž se vztahují, vedených dle common law před soudy Spojených států“‘.

Jeho kompromisní charakter tedy spočíval v tom, že ačkoliv vyzvedává právní řády jednotlivých států, zároveň ve své dikci zjevně připouští i působení common law na úrovni federálních soudů, což následně umožnilo i posuzování jednotlivých prrípadů na základě „federal common law of crimes“, přičemž toto však nevycházelo vždy nutně z právních řádů jednotlivých států, ale mělo - už s ohledem na posuzovanou problematiku - často i svůj svébytný právní základ.

To pak platí zejména pro případy velezrady, jež už kvůli charakteru svého provinění vyvolávaly pochopitelně i odpovídající mimořádnou pozornost. Situace zde přitom byla o to zajímavější, že soudům ve snaze o postižení skutkového základu tohoto „největšího možného zločinu“ nezbývalo než se dopátrat jeho dřivějšího posuzování v anglickém common law, tedy právě v právu země, proti níž spáchali zakladatelé nové americké státnosti teprve nedávno fakticky přesně tento zločin. Vedle velezrady však spadaly do rámce „federal common law of crimes“ i některé další zločiny, o jejichž posouzení federálními soudy zde taktéž alespoň stručně pojednáme.

Než však přejdeme k této problematice, je nutno si připomenout i celkový kontext, v němž americké federální soudnictví vzniká, nebot' tento má také svůj nepominutelný politický rozměr zrcadlící tehdejší rozepře mezi federalisty a republikány.

\section{Vznik amerického federálního soudnictví}

$\mathrm{Z}$ tohoto úhlu pohledu je třeba nejprve konstatovat, že požadavek zprvu v americké politice dominujících federalistů na vytvoření národní vlády, jež bude dostatečně silná, aby vyhovovala potřebám „nové doby“, se vskutku promítá i do oblasti federálního soudnictví, přičemž však právě toto má být i zárukou odpovídající ochrany osobní svobody. Uvedené výmluvně vyjadřuje i slavný esej Alexandra Hamiltona o soudnictví (jako č. 78 spadající do celku „Listy federalistů“), přičemž ale samotná federální ústava Spojených států amerických z roku 1787 hovoří o federálním soudnictví ve svém třetím článku poměrně stručně, když sice zmiňuje Nejvyšší soud USA a jeho jurisdikci, s ohledem na celou federální soustavu se však dále omezuje již jen na konstatování, že soudcovská moc náleží na této úrovni i „nižším soudům, které zrrizuje Kongres“.2

Je to tedy již v jiném kontextu zmiňovaný zákon o soudnictví z roku 1789, který se zabývá vytvořením ucelené soustavy federálního soudnictví, jehož úkolem má zcela zjevně

1 HALL, K. L. - WIECEK, W. M. - FINKELMAN, P. American Legal History (Cases and Materials). Oxford: Oxford University Press, 1991, s. 105.

2 TINDALL, G. B. - SHI, D. E. Dějiny států - USA. Praha: Nakladatelství Lidové noviny, 1994, s. 796. 
především být prosazování federálního práva v rámci jednotlivých států Unie. Konkrétně se vedle Nejvyššího soudu USA (Supreme Court) vytvářejí na federální úrovni i okresní soudy (District Courts) a obvodní soudy (Circuit Courts), přičemž v 11 státech Unie (v těch, které do té doby ratifikovaly federální ústavu) je vytvořeno 13 federálních soudních obvodů (státy Massachusetts a Virginie měly obvody dva), k nimž se pak v roce 1790 jako samostatné soudní obvody připojily i státy Severní Karolína a Rhode Island. ${ }^{3}$

Platilo přitom, že tehdy šestičlennému Nejvyššímu soudu USA byla svěřena i určitá původní jurisdikce, přičemž však základem jeho činnosti mělo být projednávání odvolání od nižších federálních soudů. Velmi důležité bylo dále i ustanovení 25. oddílu zmiňovaného zákona, které dávalo tomuto soudu možnost přezkoumávat rozhodnutí státních soudů, pokud by se dotýkala federálního práva (v tom zejména federální ústavy). ${ }^{4}$

Role nižších federálních soudů byla pak pochopitelně méně významná. V tomto textu posuzovaném trestním právu byla kupříkladu jurisdikce okresních federálních soudů vymezena výší trestů (pro prŕípady, kdy fyzické potrestání nepřesáhlo třicet ran, pokuta sto dolarů a uvěznění šest měsíců), což korespondovalo i se skutečností, že zde působil pouze jediný soudce. Nejproblematičtějším se ale již záhy ukázal být střední článek - tedy federální obvodní soud, přičemž vytvořeny byly celkem tři (Východní, Jižní a Střední). Tyto soudy totiž neměly své vlastní soudce, ale byly na svých zasedáních vytvářeny trojčlenným kolegiem, jehož jedním členem byl soudce okresního federálního soudu a zbylými dvěma potom soudci Nejvyššího soudu USA, jimž byla takto jinými slovy přiřčena tíživá a nepopulární povinnost, pro niž se vžilo už s ohledem na její charakter označení „riding on circuit".

Není tak ani divu, že právě na tuto skutečnost mířily i reformní návrhy a skutečně již zákon z roku 1793 snížil počet soudců Nejvyššího soudu USA zasedajících na obvodním federálním soudu pouze na jednoho. Zásadní změnu v tomto ohledu přinesl však až nový zákon o soudnictví z roku 1801 (podepsán v únoru tohoto roku v úřadu prezidenta již končícím federalistou Johnem Adamsem), na jehož základě byly vytvořeny úřady stálých soudců na úrovni federálních obvodních soudů, na nichž se měly nyní především odehrávat jednotlivé soudní procesy (federalisticky orientované soudce těchto soudů také ještě stačil jmenovat právě prezident Adams). Nově bylo přitom těchto soudů šest, přičemž je vytvářelo kolegium tř́i soudců, z nichž jeden soudu předsedal. ${ }^{5}$

Poté, co jsme si stručně přiblížili organizaci federálních soudů, na nichž se případy, jimiž se dále budeme zabývat, odehrávaly, je nutno říct alespoň několik slov o postavení common law v americkém právním řádu v porevolučním období, nebot’ právě „federal common law of crimes“ používané v této době na federálních soudech je stěžejním předmětem této studie.

Dlužno přitom říci, že převažující pohled veřejnosti na common law mu v tomto „zakladatelském údobí“ vůbec nebyl př́iznivě nakloněn. Toto právo je tehdy nezřídka považováno za výraz královské tyranie, svým původem a charakterem zastaralé, barbarské a feudální, kdy jeho další používání by vlastně už z principu porušovalo „důstojnost nezávislosti““. V souvislosti s tím se př́mo vytváří dokonce jakési „hnutí proti právu“ (,antilaw

SURRENCY, E. C. The Judiciary Act of 1801. The American Journal of Legal History, 1958, s. 55-57.

HALL, op. cit., s. 104.

SURRENCY, op. cit., s. 58-61. 
movement"), kdy si toto přímo vytklo za cíl redukovat právní řád v ideálním případě na nepočetný soubor lehce aplikovatelných ,„právních pravidel“ (jistým sympatiím se o něco později těšilo i právo revoluční Francie). ${ }^{6}$

Tento př́stup ke common law v sobě však i poměrně nepřehlédnutelně skrýval také značnou dávku naivity a nepokrytě utopické rysy. Společnost prostě již tehdy ke svému běžnému každodennímu fungování potřebovala daleko komplexnější právní řád, jenž by plně odpovídal ekonomickým potřebám doby, navíc v něm nemalá část Američanů i přes výše uvedené odsudky stále spatřovala důležité dědictví koloniální epochy. Ostatně mezi požadavky kolonistů přímo v revolučním období byl i ten, který zdưrazňoval jejich právo na užívání „,common law Anglie“ (zvláště byl v této souvislosti zdůrazňován nárok na porotní soudnictví, který směřoval proti snaze mateřské země přesměrovat určitou „politicky exponovanou“ část soudní agendy zejména na soudy admirality, jež soudily bez porot). ${ }^{7}$

Common law tak nakonec vítězně ustálo výše uvedené výtky a naopak se stalo v následujícím období nástrojem integrace právního řádu nového amerického státu, přičemž postupně vyhovuje i tehdy vznášeným požadavkům na jeho očistu a ,amerikanizaci“ (bez zajímavosti takto ani není, že při následném dalším osidlování „západních území“ jej místní francouzští usedlíci př́mo považují za jejich zájmům nepřátelský nástroj „amerického imperialismu“").

Souhrnně lze říci, že ,,americké common law“v dějinné zkoušce svou existenci úspěšně obhájilo v pojetí, které je považuje za „oddělený jazyk práva v rodině založené v Anglii““. 8 Co ale i nadále zůstává problematickým, je fenomén „federal common law“, o jehož rozsahu jsou zejména v oblasti trestního práva vedeny diskuse, přičemž se nakonec objasňuje hlavně rozhodováním $\mathrm{v}$ př́ípadech, jimž budeme v následujícím výkladu zejména věnovat svou pozornost.

\section{Fenomén velezrady}

Nejprve se budeme věnovat trestnému činu, který - jak již jsme naznačili - je považován za vlastně vůbec nejzávažnější možný. Ještě dříve, než se však podíváme na jeho konkrétní vyznění v americkém federálním soudnictví, je nutné se alespoň stručně zmínit o jeho dřívějším pojetí právě v anglickém common law, nebot' na ně jeho posuzování americkými federálními soudy pochopitelně v mnohém ohledu odkazuje.

V tomto kontextu vyzvedněme, že už pro svou mimořádnou závažnost je zločin velezrady (,treason“ či zastupitelný termín „high treason“) spjat neodmyslitelně i s oblastí ústavního práva, přičemž zpočátku je jeho vymezení poměrně elastické, když se v zásadě hovoří o deliktu ještě závažnějším než je „těžký zločin“ („felony“). Teprve postupně se začíná vymezovat určitěji jako pokus o velezrádnou uzurpaci moci či obecněji jako jakákoliv výzva směřující vůči vládnoucí královské autoritě, přičemž trestem zde nebyla jen smrt pachatele, ale i propadnutí jeho majetku (zejména pak půdy) ve prospěch panovníka.

Samotné určení toho, co vše je onou „,neblahou výzvou“ královské moci, zůstávalo však problematickým, a limity tohoto zločinu v rámci common law byly i nadále nejasnými,

6 FRIEDMANN, L. M. A History of American Law. New York: Simon and Schuster, 1985, s. 108-109.

7 Bliže k této problematice viz RAKOVÁ, S. Podivná revoluce (Dlouhá cesta Američanů k nezávislosti 1763-1783). Praha: Triton, 2005, s. 42-85.

8 FRIEDMANN, op. cit., s. 110-115. 
přičemž jejich konkrétní vymezení se stalo hlavně záležitostí soudů. Tak kupříkladu roku 1347 je zmiňován případ, kdy byl z velezrady obviněn muž, který uvěznil jiného, aby od něj získal zpět dlužnou částku, což bylo považováno za uzurpaci královské moci.

V souvislosti s tím zřetelně vyvstávala i potřeba tento „nejzávažnější delikt“ přesněji formulovat, protože se stávalo zřejmým, že plné přenechání této pravomoci soudům common law může zákonitě představovat i závažné ohrožení majetku, osobní svobody, a především života kohokoliv, kdo by se případně ocitl v panovníkově nemilosti. Již krátce po právě zmíněném př́ipadu je roku 1351 přijat zákon o velezradě („,Treason Act“), který skutečně na dlouhá staletí vymezil definici tohoto zločinu. ${ }^{9}$

Jako nejzávažnější je v jeho rámci spatřováno usilování o život panovníka a dalších členů královské rodiny. Dlužno přitom dodat, že za takové jednání mohlo být původně považováno už jen samotné schvalování zavraždění krále, přičemž v právní praxi však nakonec převládlo stanovisko, že je třeba prokázat, že takováto slova byla doprovázena i reálnou přípravou činu. Vedle právě zmíněného pak velezradu představuje také vedení války proti panovníkovi v jeho království, jakož i fakt pouhé př́slušnosti k jeho otevřeným nepřátelům. V př́ípadě občanské války je přitom za krále považován „de facto sovereign“, tedy ten, jemuž náležela „držba Koruny“.

Za poněkud méně závažnou (pokud ovšem lze u ze své podstaty tak závažného zločinu o „menší závažnosti“ vůbec hovořit) formu velezrady je pak považováno i padělání „velké pečeti“ či mincí v království, přičemž tzv. ,petit treason“ (odtud tedy i naopak termín „high treason“) představovalo i zavraždění manžela manželkou, pána jeho sluhou, či duchovního představeného mnichem, což s ohledem na zvláštní charakter vztahů mezi uvedenými znamenalo právě tuto právní kvalifikaci zločinu, závažnější než vražda, a znamenající tak i tvrdší trest bez možností se mu vyhnout díky využití právního institutu „benefit of clergy“ (,petit treason“ byl „,redukován“ na vraždu roku 1828). ${ }^{10}$

Právě uvedené představuje tedy základ pro právní posouzení zločinu velezrady i na konci 18. století v období po založení nové americké státnosti. Jak patrno, americké federální soudy se musí vyrovnat s tím, že právní úprava - v této době ve Velké Británii stále platná - této problematiky sahá jednak hluboko do středověku, jednak je už ze své podstaty koncentrovaná především na delikty namířené proti panovníkovi a jeho zájmům.

To pak - jak i naznačeno výše - představovalo pro Spojené státy americké problém už v tom ohledu, že jejich nová vlastní státnost vznikla z jednání, jež Britové sami nepochybně vnímali jako velezrádné, přičemž oprávněnost tohoto pohledu uznávali (alespoň tedy v počátcích roztržky) i sami kolonisté. Tak třeba přední americký právník James Otis ve svém textu z roku 1764 „Práva britských kolonií“ („The Rights of the British Colonies“) se sice silně angažuje v úsilí o zajištění plného rozsahu práv Američanů, na straně druhé však i uznává, že „Parlament Velké Británie má nad jemu podřizenými vládami nezpochybnitelnou moc a zákonnou autoritu přijímat zákony $\mathrm{k}$ jejich obecnému dobru, které pro ně ve svém výčtu jsou a mají být stejně závazné jako pro občany Velké Británie žijící přímo na území jejího království“, přičemž „násilné odporování zákonům Parlamentu a Krále je velezradou". 11

9 BAKER, J. H. An Introduction to English Legal History. London: Butterworths, 1990, s. 599.

10 Tamtéž, s. 600.

11 HALL, op. cit., s. 61. 
Nicméně přesně toho se ,z logiky revoluce“ kolonisté nakonec ve vztahu k „,mateřské zemi“ dopustili, přičemž nyní ale sami stáli před výzvou, jak v konkrétních soudních př́ípadech uchopit „velezrádné výzvy“ vůči vlastní nové státnosti, a jak tedy jinými slovy co nejrozhodněji zajistit její zájmy, přičemž jim však nezbývalo než se vrátit k výše popsanému pojetí velezrady v anglickém právu, a vzít ho přes veškerou paradoxnost nastalé situace při chybějící přesné legislativní úpravě jako jediné nabízející se východisko pro smysluplné řešení situace.

A to bylo nezbytné už proto, že zmíněné „,velezrádné výzvy“, na něž bylo nutno bezpodmínečně se vším možným důrazem reagovat, se objevily dříve, než mnozí očekávali. V realitě je pak představovaly zejména ozbrojené pokusy o vzdor proti nové státní moci ještě v údobí „konfederačního uspořádání státu“, z nichž nejvýznamnější bylo tzv. „Shaysovo povstání"v Massachusetts v lednu 1787. To bylo považováno za jeden ze symptomů prohlubující se anarchie v zemi, což pak bylo i významným impulsem pro šírící se přesvědčení, že tehdejší klíčová ústavní listina země „Články konfederace“ neposkytuje nové republikánské vládě dostatečnou základnu pro její efektivní správu, a situaci je třeba řešit posílením ústřední autority. ${ }^{12}$

Nicméně ani po přijetí a ratifikaci nové federální ústavy v roce 1788 ozbrojené výzvy vůči americké státnosti neustaly. Z nich nejzávažnější byla tzv. „,whisková rebelie“, jíž musí naše pozornost patřit už proto, že v reakci na ni a její úspěšné potlačení dochází ke konání soudních procesů, na nichž je zločin ,velezrady“ i v americkém právu nově diskutován a posuzován.

\section{Trestný čin velezrady na amerických federálních soudech}

Ze skutkového hlediska šlo přitom o to, že federální spotřební daň z roku 1791 zasáhla těžce především ekonomii západních pensylvánských okresů, v nichž byla výroba whisky vnímána jako nejlepší způsob podnikání, na čemž nic neměnila ani její zdejší a ve srovnání s jinými částmi amerického území poměrně nízká cena. To však nyní změnila výše zmíněná daň, jež zasadila zdejší na pálení whisky do značné míry založené ekonomice velikou ránu, takže tato daň přestala být mnohými místními podnikateli odváděna a federální autorita nakonec v této oblasti přestala dokonce na několik měsíců fakticky existovat.

Situace následně zašla až tak daleko, že když se výběrčí daní pokusili v červenci roku 1794 pohnat asi 60 neplatičů daně k federálnímu soudu ve Filadelfii, byl vypálen dům hlavního výběrčího daní a zabit jeden voják, takže na podzim téhož roku bylo nutno povolat federální oddíly, jež nakonec tuto rebelii úspěšně potlačily. V právní rovině se pak se vzpourou vypořádává v roce 1795 obvodní federální soud („United States Circuit Court for the District of Pennsylvania“) ve Filadelfii, před který byli vůdci vzbouřenců s obviněním ze spáchání trestného činu velezrady pohnáni (připomeňme v této souvislosti již výše uvedenou skutečnost, že po úpravě z roku 1793 zasedali na tomto stupni federálních soudů jen dva soudci, z nichž už pouze jeden byl členem Nejvyššího soudu USA). ${ }^{13}$

12 Blíže k této problematice viz LUTZ, D. S. The Origins of American Constitutionalism. Baton Rouge: Louisiana State University Press, 1988, s. 125-149.

13 PRESSER, S. B. - ZAINALDIN, J. S. Law and Jurisprudence in American History (Cases and Materials). St. Paul: West Publishing Company, 1989, s. 151-152. 
Konkrétně pak vystupují do popředí dva př́pady, z nichž prvý „The United States v. Vigol“ je postaven na obžalobě pro velezradu spočívající ve vedení války proti Spojeným státům americkým, přičemž tatáž obžaloba zazní i v druhém př́ipadu - „The United States v. Mitchell““. A je to právě naposledy uvedený, který nám umožňuje ve své dochované a ve srovnání s prvým př́ípadem mnohem obsáhlejší argumentaci mezi obhajobou a obžalobou nazřít podrobněji tehdejší právní konstrukci zločinu velezrady.

Po výpovědích svědků je to právě žalobce Rawle, který představuje své pojetí koncepce velezrady v daném př́ípadě. Podle něj je třeba se vrátit už ke skutečnosti, že ,vedení války“ proti zákonné vládě v sobě nutně obsahuje „technicky vzato“ velezradu, protože v tomto smyslu je jedno, má-li v daném okamžiku republikánskou či monarchickou formu, a již v královské Anglii (jak jsme ostatně výše také uvedli) bylo takovéto počínání jako velezrada kvalifikováno.

Rawle dále v této souvislosti výslovně upřesňuje, co znamená „vést válku“ proti zákonné vládě: „u anglických autorit je jednomyslně a jasně prohlášeno, že sdružit muže za účelem dosáhnout zastrašováním či násilím odvolání zákona, nebo oponovat či zamezit násilím výkonu práva, představuje vedení války“. Zároveň přitom rozlišuje mezi pouhou konspirací s cílem vést válku, jež ještě velezradu nezakládá, a povstáním s cílem potlačit činnost veřejných úřadů, jež se jí už rovná. Konečně zdůrazňuje, že pokud konspirace skutečně přeroste ve vedení války, pak jsou velezradou vinni všichni ti, kteří se už na fázi konspirace podíleli, přičemž ti, kdo původně nebyli na spiknutí zúčastněni, ale přidali se až následně, jsou stejně vinni jako původní spiklenci, nebot' u zločinu velezrady náleží vlastně všem ,hlavní role“. 14

Obhájce obžalovaného Mitchella pod tlakem již dříve přednesených svědectví následně konstatoval, že jeho záměrem není dokázat, že dotyčný je zcela nevinný ve smyslu, že by mu nemohlo být prokázáno spáchání žádného trestného činu, at’ už proti Spojeným státům americkým, či státu Pensylvánie, nicméně odmítl žalobcem předestřené obvinění ze zločinu velezrady, čímž se zákonitě dostal i k jejímu vymezení.

Podle něj je v Anglii vypracované pojetí zločinu velezrady samo o sobě diskutabilní, $\mathrm{k}$ čemuž se v daném př́padě bohužel připojuje i snaha žalobce prakticky zrušit všechno moudré rozlišení ve stupních páchaných deliktů, kdy pouhé shromáždění davu označí za konspiraci a nepokoje hned povýší na velezradu. Dále argumentuje, že podle něj faktickým jednáním obžalovaného došlo $\mathrm{k}$ pouhému přečinu (,misdemeanour“), v žádném případě však k velezradě, nebot' původní snahou shromážděného davu nebyla konspirace za účelem vedení války, ale pouhá porada, jejímž cílem bylo rozhodnout, co by bylo za daného stavu věcí nejlepším učinit. Následné a okamžitými impulsy vyvolané násilí je sice jistě politováníhodné, nezakládá však ,vedení války“ proti Spojeným státům americkým, jež by se rovnalo zločinu velezrady. $O$ ten by šlo pouze při snaze cíleně vyvolat všeobecné povstání, což ovšem nebyl tento př́ípad.

Soudní spor byl následně předán k posouzení porotě, kdy velmi zajímavý dokument v této souvislosti představují i příslušné instrukce, jež jí byly předány soudcem Patersonem. Ten přitom zdůrazňuje, že prvořadým úkolem poroty je ujasnit si, co bylo hlavním cílem vzpoury, jež na části území Pensylvánie proběhla. Pokud to totiž byla snaha zamezit hrozbou a silou činnosti daňových úřadů, jakož i znemožnění uvést v život zákon

Tamtéž, s. 153-154. 
Kongresu, pak spáchaný čin nelze právně ohodnotit jinak než právě jako velezradu. To by neplatilo pouze tehdy, pokud by toto násilí bylo motivováno pomstou vůči daňovým úředníkům jako ,soukromým osobám“.

Paterson se přitom netají - a je za to následně i kritizován -, že podle něj bylo nad veškerou pochybnost výpověd'mi svědků prokázáno, že jednání vzbouřenců (a tedy i obžalovaného Mitchella) nebylo v žádném případě vedeno osobní nenávistí, ale bylo svým charakterem obecné povahy, tedy té, jež zakládá zločin velezrady. Paterson jde konečně až tak daleko, že uvádí, že shromážděné důkazy znamenají, že obžalovaný musí být prohlášen vinným, čímž jde pochopitelně daleko nad běžný rámec, kterým se obecně instrukce porotě ze strany soudů vyznačují (ty by měly zdůraznit pouze otázky, jež by porota měla při svém rozhodování o vině uvážit, nikoliv ji však př́mo ovlivňovat v tom, jaký závěr by měla z předloženého důkazního materiálu vyvodit).

Dlužno přitom poznamenat, že nekompromisní stanovisko, jež soudce Paterson k projevům lidové nespokojenosti zaujal, skutečně příliš nekoresponduje s tehdejším náhledem na obdobné dění v koloniálním údobí, v němž byl naopak spatřován výraz odporu vůči koloniální autoritě za zdravý projev lidové vůle ve jménu svobody, ba dokonce i za svého druhu poněkud drsnou medicínu nezbytnou pro uchování „zdraví vlády“. V uvedeném př́ípadě je však Mitchell nakonec porotou skutečně shledán vinným, přičemž však před velezradě odpovídajícím trestem smrti jej nakonec uchránila milost udělená prezidentem Washingtonem. ${ }^{15}$

Tento případ však skutečně dobře dokumentuje proměnu amerického smýšlení ve vztahu k davovému násilí a lidovým povstáním, jež jsou nyní - v situaci, kdy Američané mají svou legální vládu - neakceptovatelné a jenom zbytečně diskreditují novou americkou státnost v očích evropských národů. Nápravu lze totiž velmi jednoduše, a především v plném souladu s teorií lidové vlády zjednat díky svobodným volbám. Tento postoj se plně odráží i při posuzování další „,rebelie“, jež se odehrála pět let po právě zmíněných událostech, opět na území Pensylvánie, tentokráte však v její východní části.

Podnětem přitom byla poněkud paradoxně skutečnost, že náklady na potlačení whiskové rebelie spojené zejména s nutností zabezpečit federální oddíly, bylo nutno logicky opět pokrýt z federálních daní, tentokráte uvalených na vlastníky domů. Opět tak vzniká odpor proti vybírání těchto daní, jenž tentokráte sice nebyl doprovázen krveprolitím, přesto však při něm došlo i k protiprávnímu osvobození vězňủ z vazby federálního velitele místní policie. Vůdčí postava této „osvobozovací akce“ John Fries (podle něj se tak někdy nazývají tehdejší události přímo jako „Fries Rebellion“) je obžalován opět ze zločinu velezrady, jež soudí místní federální obvodní soud, na němž zasedají soudcové Peters a Iredell. ${ }^{16}$

Druhý zmiňovaný je pak zajímavý i svým stanoviskem ve známé rozepři se soudcem Chasem (který - jak ještě uvidíme - bude hrát v námi sledované problematice také svou nepominutelnou roli) v prrípadu Calder v. Bull z roku 1798, v němž šlo o otázku možné aplikace přirozeného práva (přesněji ,higher-law doctrine“) při posuzování přijaté legislativy soudní mocí. Zatímco Chase v tomto smyslu zdůrazňuje, že ,„pozitivním právem tak nelze ospravedlnit žádnou jasnou nespravedlnost, nelze zrušit bezpečí osobní svobody ani

15 Tamtéž, s. $154-158$.

16 Tamtéž, s. 160-161. 
soukromého majetku“, zastává Iredell stanovisko, podle nějž sice „někteří hloubaví právníci považují jakýkoli legislativní počin odporující přirozenému právu za neplatný sám o sobě. Domnívám se však, že by žádný soudní dvưr tvořící součást zmíněné vládní moci nebyl oprávněn něco takového prohlásit.“A to už proto, že ,„představy o přirozeném právu se neřídí žádnými ustálenými měřítky. V názorech na tuto otázku se často neshodovali ani nejschopnější a nejmravnější muži. Soud by tedy v daném př́padě nemohl prohlásit nic než to, že legislativa (mající stejné právo na vlastní názor) přijala zákon, který se podle mínění soudců neslučuje s abstraktními principy přirozené spravedlnosti.“17

Po tomto malém - leč nikoliv nezajímavém a právní filosofii soudce Iredella dobře dokreslujícím - odbočení se vrat’me k procesu Johna Friese, v němž je tento obžalován jako hlavní aktér rebelie, jež vedla až k protiprávnímu osvobození „federálních vězňư“, což mu vyneslo obžalobu z velezrady. Jeho obhájci přitom jsou dřivější federální soudce William Lewis a Alexander James Dallas, jejichž argumenty jsou mimo jiné i nepokrytě namířeny ke snaze vyvolat v místním obyvatelstvu široké sympatie s jednáním obžalovaného.

V souladu s tím se také snaží o přesunutí projednávání př́ípadu z Filadelfie do northamptonského okresu, v němž byl trestný čin spáchán, a to s odvoláním na 29. oddíl zákona o soudnictví, podle něhož má být soud konán na místě, kde došlo k protiprávnímu jednání. To však oba soudci odmítají s konstatováním, že pokud byl prakticky celý tento okres ve stavu vzpoury vůči federální moci, potom lze jen stěží očekávat, že by zde mohl proběhnout nestranný a spravedlivý proces.

Pokud se pak zaměříme na věcnou argumentaci obhájců, je zde podobně jako u již zmíněných př́padů patrná snaha odmítnout právní kvalifikaci případu jako velezrady, nebot' takováto v př́padě, že je obžalovaný shledán vinným, na sebe zákonitě přitahuje i nejvyšší trestní sazbu v podobě udělení trestu smrti. Oba shodně tvrdí, že ozbrojený odpor vůči federálním orgánům při vynucování federálního zákonodárství nepředstavuje nutně sám o sobě zločin velezrady. Napadeno je v této souvislosti poměrně logicky i rozhodnutí v př́ipadu Mitchell, o němž obhájci tvrdili, že bylo „stejně nesoudné jako nejhorší názor přijatý v nejhorších dobách Anglie“.

A právě pojetí zločinu velezrady v common law Anglie následně věnují Lewis i Dallas svou pozornost. Podle nich zdejší příliš široká definice velezrady vedla zákonitě i k tyranii královské moci, což oba právníci dokládají také citacemi případů, jež mají přítomné a zejména pak pochopitelně porotu vést $\mathrm{k}$ přesvědčení, že už v samotné historii trestného činu velezrady je nemálo absurdit. Zmíněn je kupř́ikladu i případ, kdy vlastník hostince pojmenoval svůj podnik „Znamení Koruny“, načež o svém synovi tvrdil, že je „dědicem Koruny“, což mu vyneslo obvinění z velezrady.

Podobně pak oba obhájci tvrdili, že i precedent dokládající, že ,záchrana vězňư“ z rukou oficiálních autorit je velezradou, pochází z doby absolutistické vlády krále Jindřicha VIII., a porota by mu tudíž jako „despotickému excesu“ neměla přikládat žádnou právní váhu. Právě naopak by mělo být nyní v již svobodné americké republice pojetí velezrady velmi limitované, přičemž její naplnění skrze ,vedení války proti vládě“ by mělo být omezeno jen na případy, kdy se ozbrojení muži přímo pokusí o svržení vlády nebo kdy se část území násilím pokusí odvrhnout autoritu Spojených států amerických. Velezradou však není, pokud se vzbouřenci pouze pokusí zabránit uvedení zákonů republiky do praxe. Zde by

17 HALL, op. cit., s. 108-109. 
šlo - tedy stále v pojetí obou právníků - v rámci common law hovořit pouze o trestném činu pobuřování (,sedition“) nebo pomoci k útěku (,,rescue“), v žádném př́ípadě však o hrdelním zločinu velezrady. ${ }^{18}$

Jinak to však viděl ve svých instrukcích porotě soudce Peters, který se opět vztáhl zejména $\mathrm{k}$ předchozím př́padům whiskové rebelie a zdůraznil, že je velezradou zabránit silou či zastrašováním výkonu (nebo dosáhnout odvolání) práva Spojených států, nebot' takto jsou „práva všech napadena násilím několika“ a je zasazen smrtelný úder vládě nutně závisející ve svém fungování právě na výběru daní.

Není přitom ani bez zajímavosti, že soudce Iredell se ve zřejmém vymezení se k postoji soudce Patersona „,v př́padu Mitchell“ zřetelně zřekl možnosti jakkoliv svým úsudkem ovlivňovat porotu, když výslovně konstatoval, že není úlohou soudu vyjádřit svůj vlastní názor, zda byl naplněn velezrádný záměr ve smyslu obžaloby, nebot' toto náleží porotě úlohou soudu je pouze objasnit porotcům stav právní úpravy, jež se k posouzení prŕípadu vztahuje.

Samotná porota nakonec vyřkla nad Johnem Friesem verdikt „vinen“, což bylo vzhledem k výkonu obhájců shledáno spíše překvapivým a přičítalo se zejména tomu, že veřejné mínění ve Filadelfii, kde se proces odehrál, bylo silně zaměřeno proti „venkovským vzbouřencům“, a nezůstalo ani bez vlivu na rozhodnutí porotců. A právě údajná podjatost jednoho z porotců je nakonec i důvodem, proč je Friesovi přiřčeno právo na nový proces. Konkrétně šlo přitom o to, že se porotce John Rhoad podle svědků již poté, co byl vybrán do poroty, ale ještě předtím, než začal samotný proces, vyjádřil v tom smyslu, že „Fries má být pověšen“. Soudce Peters se přitom na rozdíl od Iredella zprvu nedomníval, že tento výrok zakládá právo odsouzeného na opakování procesu, nebot' Rhoad i v případě, že by takový výrok skutečně pronesl, pouze reflektoval, jak se tehdy celá záležitost jevila veřejnému mínění, nakonec se však zdráhavě k Iredellově mínění připojil. ${ }^{19}$

Druhý proces Johna Friese na obvodním federálním soudu pak začíná v dubnu roku 1800, kdy jedním ze soudců je opět Peters, jehož však tentokráte doplnil Iredellův protivník ve sporu o fenomén přirozeného práva Samuel Chase. Právě tento soudce je i stoupencem přístupu, podle nějž se má v tomto procesu zamezit plýtváním času na citace nepodstatných autorit a zbytečné diskuse. Za tímto účelem dále podnikl Chase i nikoliv zcela obvyklý krok spočívající ve skutečnosti, že sepsal „náhled soudu“ na to, jaké právo je relevantní pro daný př́pad, aby tím odradil obhájce od další možné argumentace v tomto směru. ${ }^{20}$

Zcela konkrétně pak tvrdil, že pro př́ípad je určující pojetí trestného činu velezrady, tak jak bylo zejména vyjádřeno $\mathrm{v}$ procesech vztahujících se $\mathrm{k}$ whiskové rebelii, a jehož jádrem je právní přesvědčení, že ozbrojený odpor vůči právu Spojených států amerických představuje velezradu. Je tedy zcela zbytečné ztrácet čas tím, že se budou porotě představovat jakési absurdní případy z dávné anglické historie. V neskrývaně pobouřené reakci na tento postup pak oba obhájci z prvého Friesova případu Dallas i Lewis ohlásili svůj záměr dále

18 PRESSER - ZAINALDIN, op. cit., s. 161-162.

19 Tamtéž, s. 162-163.

20 Připomeňme v této souvislosti, že poněkud ,,autoritativní povaha“ soudce Chase vedla nakonec i k známému ,impeachmentu“ tohoto soudce v Senátu. Roku 1805 byl ale nakonec Chase zbaven tímto orgánem obvinění ve všech bodech obžaloby. Bliže k této problematice viz LILLICH, R. B. The Chase Impeachment. The American Journal of Legal History, 1960, s. 51-70. 
se nepodílet na projednávání př́ípadu, v němž jim byly soudem dle jejich mínění zcela nepř́ípustně takto nastaveny mantinely pro argumentaci.

Následný pokus o smír, o nějž se pokusil nám již taktéž známý žalobce př́ípadu Rawle, nakonec skončil neúspěchem, který byl podtržen i skutečností, že Fries odmítl jiné obhájce a rozhodl se hájit sám, což bylo však zřejmě motivováno i skutečností, že tento př́istup měl vzbudit také sympatie veřejnosti a přispět k případnému udělení prezidentské milosti v případě odsouzení. Ostatně sám Rawle v průběhu procesu opakovaně zmínil, že je mu postavení žalobce $\mathrm{v}$ situaci, kdy obžalovaný nemá $\mathrm{k}$ dispozici odpovídající právní pomoc, a to navíc, když je proti němu vznesena „největší myslitelná žaloba“, osobně velmi nepř́ijemné.

Rawle nejprve ve své řeči shrnuje skutkovou podstatu př́ípadu, kdy považuje za dřívějšími svědeckými výpověd'mi prokázané, že Fries byl vůdčí postavou dění směřujícího k nezákonnému osvobození federálních vězňů, čímž se dopustil vedení války vůči Spojeným státům, a tak i trestného činu velezrady. Sám se přitom i vrací ještě k soudním procesům týkajícím se velezrady z anglické právní minulosti, přičemž zdůrazňuje, že citování případů z této doby by se mělo týkat pouze vedení války proti královské vládě, nikoliv však vzpoury proti osobám jednotlivých panovníků.

Vzhledem k již zmíněné nepř́ítomnosti obhájců v tomto procesu se tak v jeho dalším průběhu jednalo především o výměnu argumentů mezi žalobcem Rawlem a oběma soudci, z nichž především Chase opakovaně konstatoval, že by v celém projednávání měla být pominuta role trestného činu velezrady v anglickém právu při pouhém omezení se na to, jak byl tento zločin pojat $\mathrm{v}$ případech vztahujících se $\mathrm{k}$ whiskové rebelii.

Chase nakonec shrnuje ve své řeči tento právní náhled, kterého by se porota měla dle jeho názoru při svém rozhodování přidržet, přičemž zdůrazňuje, že obžalovaným spáchaný zločin velezrady je vůbec tím největším myslitelným, jakého se může člověk dopustit. Samotný Fries, jenž zaujal bez př́tomnosti svých obhájců během procesu prakticky zcela pasivní postoj, je nakonec porotou shledán opětovně vinným, odsouzen k trestu smrti oběšením, jenž je mu ale nakonec cestou prezidentské milosti prominut. ${ }^{21}$

\section{Další případy ,federal common law of crimes“}

Jak už ale řečeno v úvodu této studie, nebyl to jen zločin velezrady, jenž nás opravňuje hovořit o užití „federálního common law“ na amerických federálních soudech v prvých desetiletích po založení nové americké státnosti. Jelikož však již také zmiňovaný zákon o soudnictví z roku 1789 poskytoval v tomto směru jen poměrně vágní vodítko, když hovoří o zločinech podléhajících soudní autoritě Spojených států, byla to nakonec především soudní praxe, jež určila, co do takto vymezené jurisdikce vlastně spadá.

Fakticky bylo rozhodující, jaké konkrétní trestné činy byly před federálními soudy žalovány. Obecně přitom panovalo přesvědčení, že jsou to v prvé řadě ty, v nichž se vyskytuje „mezinárodní prvek“, nebot’ Spojené státy americké podle tehdejších teorií „právo národů“ („law of nations“) do svého právního řádu inkorporovaly. Dobře to dokládá již př́ípad z roku 1793, kdy je vzneseno obvinění proti Gideonu Henfieldovi, který byl obviněn z toho, že se zapojil do jednání neprátelského národům žijícím v míru se Spojenými státy americkými.

21 PRESSER - ZAINALDIN, op. cit., s. 164-177. 
Konkrétně šlo přitom o to, že Henfield se jako americký občan podílel na ukořistění anglické lodi francouzskými mořskými lupiči, čímž se podle soudce Wilsona provinil proti „základům civilizované jurisprudence“, jež v jeho zemi představuje systém common law. Henfield je tedy obžalován s tím, že se dopustil porušení neutrality svého státu nepřátelským aktem vůči jinému státu, přičemž také porušil právo své vlastní země jednáním odporujícím ,právu národů“ převzatému do celku common law.

Samotný proces probíhal shodou okolností opět na pensylvánském federálním obvodním soudu, přičemž obžalovaný se bránil nejprve konstatováním, že netušil, že svým jednáním porušuje neutralitu Spojených států amerických, což ale později změnil na tvrzení, že je stoupencem ,francouzské věci“, ba že se přímo považuje za Francouze a zamýšlí se i se svou rodinou odstěhovat na její území.

Soud následně konstatoval, že právo emigrace pochopitelně náleží každému svobodnému člověku, pro posouzení daného prrípadu je však určující, zda k ní došlo už před spácháním „,neprrátelského aktu“, a zda tedy v dané době byl Henfield stále ještě občanem Spojených států či již nikoliv. Porota se po tomto právním vymezení př́ípadu soudem nakonec rozhodla pro verdikt ,nevinen“. 22

Jiným případem, kde došlo při soudním projednávání k výslovnému uplatnění „,práva národů“ jako práva Spojených států amerických, byl i proces s janovským konzulem Ravarou, který byl roku 1793 opět před stejným pensylvánským soudem obviněn z vydírání. Soud přitom konstatoval, že jeho konzulská hodnost nezakládá nárok na vynětí z trestního stíhání, načež jej po důkazním řízení shledala porota vinným.

Mezi př́ípady, v nichž došlo v tomto období k uplatnění federal common law, dále patří i proces „The United States v. Robert Worrall“, projednávaný před pensylvánským federálním obvodním soudem roku 1798, v němž byl Worrall obžalován z pokusu podplatit daňového komisaře Spojených států. Toto jednání je soudem výslovně považováno za trestný čin v rámci common law, jež je zároveň právem Spojených států. Obžalovaný je nakonec shledán vinným a odsouzen k uvěznění na dobu tří měsíců a zaplacení pokuty dvou set dolarů. ${ }^{23}$

\section{Závěrem}

Souhrnně můžeme říci, že federal common law se v praxi federálních soudů, jak jsme mohli vidět na příkladu právě uvedených soudních případů (jež se shodou okolností odehrály na federálním obvodním soudu státu Pensylvánie), opravdu prosadilo a bylo fakticky aplikováno. Šlo přitom hlavně o prŕípady velezrady a některé další trestné činy, u nichž byl zejména přítomen prvek ,práva národů“, jež bylo považované za součást právního řádu Spojených států amerických.

Již tehdy se však objevují i hlasy, které namítají, že common law bylo původně pouze právem jednotlivých kolonií, kdy některé z něj navíc převzaly do svých právních řádů něco, co jiné naopak odmítly, a že tak o nějakém jasně vymezeném ,federal common law“ může být po vzniku Spojených států amerických jen stěží řeč. Požadováno je už z důvodu právní jistoty jasné zákonné vymezení federálních zločinů, k čemuž následně skutečně i dochází. Dobrým př́kladem jsou v tomto směru ostatně už i některé zákony

\footnotetext{
22 Tamtéž, s. 181-186.
}

23 Tamtéž, s. 187-194. 
z doby prezidentské administrativy federalisty Johna Adamse (zejména „zákon o pobuřováni'“ z roku 1798), na čemž nic nemění ani skutečnost, že se následně staly předmětem vyostřeného politického boje právě mezi federalisty a republikány vedenými budoucím prezidentem Thomasem Jeffersonem. ${ }^{24}$

Celé téma je přitom důležité už proto, že ukazuje, jak si právní řád teprve pozvolna se formující federace začíná vytvářet i odpovídající federální trestní právo, čímž nepochybně přispívá i k tolik potřebnému vědomí nové ,,americké jednoty“.

24 Blíže viz HALL, op. cit., s. 98-101. 